\title{
THE TRADITIONS OF FISTICUFFS IN THE NORTH-WEST OF RUSSIA FROM THE EARLY MIDDLE AGES TO THE MODERN ERA
}

\author{
Dmitry Belyukov
}

\begin{abstract}
Various forms of physical training were widespread in the national culture of the East Slavs. One of its original forms was fisticuffs. North-west of Russia was not an exception. There was a fisticuffs version called Skobar, which was practised in the territory where the Krivichi, the powerful union of the East Slavic tribes, used to live. One of the versions explains the word Skobar as an alteration of Pskovar, which denotes an inhabitant of the Pskov region.

Traditions of fisticuffs are known to have continued up to the second half of the 19th century. Their descriptions published in the magazine Pchela (The Bee) in 1878 have survived until today. So, for example, in Pskov fights were held 'wall on wall - in an avalanche', some hundreds of people on each side.

Other cities of the province were famous for fisticuffs as well. In Velikie Luki they were a usual youth entertainment at Christmastide and Shrovetide. Competitions were generally held in the city suburbs. City dwellers set out on a fight against peasants of Sergievskaya village, which was part of the city suburbs.

At the end of the 19th century fisticuffs were banned by the authorities. But this prohibition was not always observed. Writer Yury Tynyanov mentioned that during his schooldays (1904) fisticuffs were held between city suburbs that were at war, and the pupils of Pskov Grammar School participated in them.
\end{abstract}

Keywords: north-west of Russia, Pskov region, Krivichi, Skobar, city suburbs, fisticuffs

Already in ancient times various forms of physical training were widespread in the national culture of the East Slavs. One of its original forms was fisticuffs. It is a known fact that fisticuffs was practised by the Slavs in the 9 th century. But later on the custom of fisticuffs disappeared both by the West and East Slavs. So, the question stands: why has the custom of fisticuffs that disappeared at some Slavic tribes survived at the East Slavs? Historians maintain that it can be connected with the use of fisticuffs in military science. Russian statehood was formed in the conditions of constant struggle against the nomadic people of Asia. Later on, in the 13th-15th centuries, Russia sustained more than 160 wars with Tatars, Lithuanians, German knights, Swedes, Poles, Hungarians, Bulgarians, etc. 


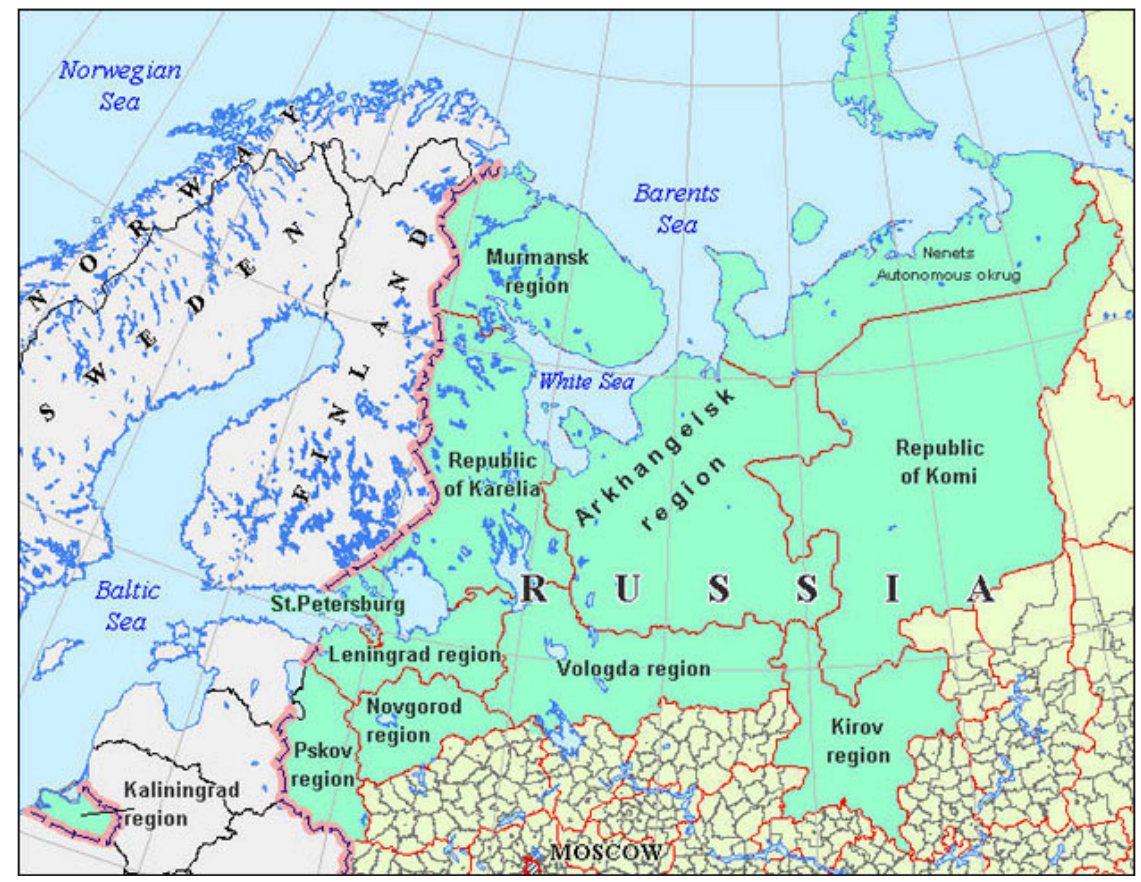

Figure 1. Map of north-west Russia. (http:/ /openbudget.karelia.ru/budnord/english / nord11_nav.htm)

Two principal kinds of fisticuffs were distinguished - group (wall on wall) and single (one on one). The fight 'one on one' was close to old English bare-knuckle boxing, but differed from it by its smaller cruelty. Before beginning the fight, the contestants embraced three times and kissed each other, showing the absence of any enmity between them. In case one of the fighters fell, the fight was stopped, while in English boxing beating of the lying contestant continued (it was banned only in 1743) (Goloshchapov 2007: 77-78).

However, mass fights 'a wall on a wall' were the most favourite and the most widespread in Russia. In group fisticuffs streets, city districts, and villages usually met, and participants were grouped according to age. As a rule, fights were arranged on holidays - in special places in the summer, on the ice of frozen rivers and lakes in the winter. Fisticuffs was formed and became established during less than one century. The first important step was full elimination of stick fighting. Fisticuffs became an exclusively unarmed fight. Further on, kicking was forbidden as well as the use of feet for throws. In many districts there were differences in rules, but in due course they became almost uniform for all Russia. 
At the same time in the upper class, among the nobility, a negative and contemptuous attitude towards fisticuffs strongly persisted. The majority of Russian tsars tried to ban the practising of the fight but all their attempts appeared to be in vain. There were objective reasons for that. Fisticuffs was an embodiment of military preparation in physical training.

Participants in the fights were to observe unwritten but strict rules: not to beat the downed opponent, not to hide anything in the gloves, fight face to face, breast to breast, not to trip, etc. (Stolbov \& Finogenova \& Melnikova 2001: 112-113).

Popularity and love of Russian people for this entertainment is reflected in the literary works of outstanding Russian writers: A. Pushkin, M. Lermontov, L. Tolstoy, A. Gorky, M. Sholokhov, etc., and depicted by artists I. Repin, V. Vasnetsov, M. Vrubel, etc., and composers A. Borodin, A. Grechaninov, etc.

In The Legend about Ivan Vasilevich, Young Oprichnik and Kalashnikov's Bold Merchant, M. Lermontov described the fisticuffs between the tsar's oprichnik Kiribeevich and merchant Kalashnikov. Kalashnikov won, having defended

Figure 2. V. Vasnetsov. Kiribeevich fighting with merchant Kalashnikov. 1891. (http:// panevin.ru/calendar/big / ukaz_o_zaprete_kulachnih_boev. html)

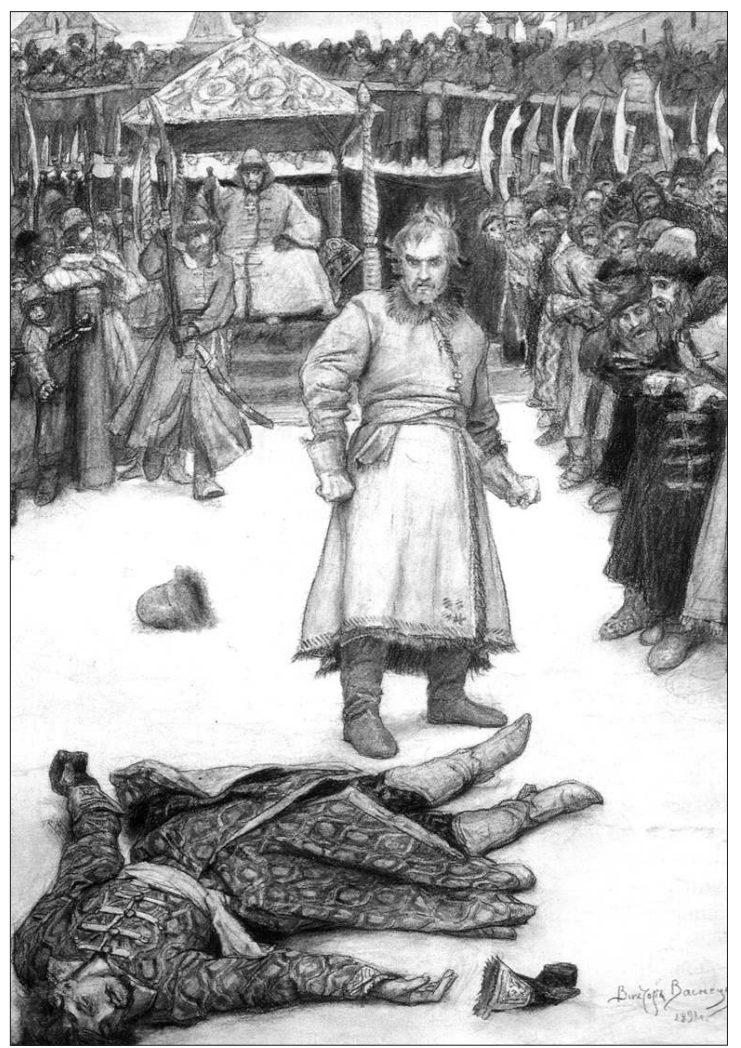


the honour of a lady offended by Kiribeevich, and "having stood for the truth to the end", but he was later on executed by tsar Ivan Vasilevich (Lermontov 1988: 515-529).

Maxim Gorky in the novel Matvey Koshemyakin's Life has described the fisticuffs as follows:

Townspeople carry on the fight cunningly [...] move out of their 'wall' against the mass of settlement dwellers about five good fighters, and when settlement dwellers, charging at them, involuntarily try to force their way like a wedge, the townspeople unanimously strike from the sides, trying to crush the enemy. But the settlement dwellers are used to these manners: they quickly withdraw and seize the townspeople in a semicircle... (Gorky 1949).

In each fight, in particular a very crowded one, some of the contestants were heavily beaten, crippled or even killed. On the trampled snow, on the river ice, there were motionless bodies lying around, and their companions took them away, or sometimes the police interfered. The victims' involuntary, casual mutilations could not specify if it was a matter of revenge, enmity or something else. And how to save yourself, when in a heat of passion, in the crowd, a blow is delivered unintentionally by such part of the body that injures or even causes death.

One of such cases took place in 1823 during the travel of the Emperor Alexander I to the south. The emperor was dissatisfied with the incident and

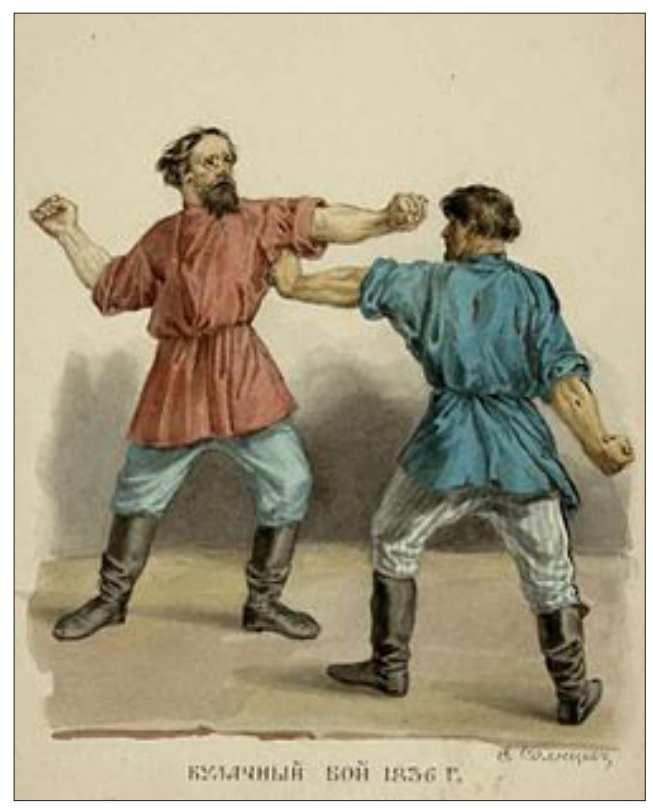
issued a decree as of October 20 to ban fisticuffs.

Prohibition of the fisticuffs was included into the Code of Laws of the Russian Empire in 1832 (Volume 14, part IV, article 180) (Code of Laws 1832): "The fisticuffs as harmful entertainment is completely forbidden". The same is literally repeated in the editions of $1839,1842,1857$, 1876 and 1890.

Figure 3. F. Solntsev. Fisticuffs. 1836. (http://www.posterlux.ru/ rus-artists/gallery/solncev-fedorgrigorevich-1801-1892/9685/page/1) 
Nevertheless, the fisticuffs was practised almost everywhere, even in the capital, although in the latter it was practiced not so often and not in such volumes.

Certainly, the north-west of Russia and the Pskov region were not an exception. There was even a variant of fisticuffs called Skobar, in which lines of ceremonial dancing can be easily recognised. In the Pskov region its name is not only Skobar but also 'affectation', which means to pretend or dance as a drunken person. In general, a similar dance can be met all over the territory where the Krivichi - the powerful union of the East Slavic tribes - used to live.

One of the versions explains the word Skobar as an alteration of Pskovar, which denotes an inhabitant of the Pskov region. They pretended to be drunk when dancing to a folk tune played on the accordion. The motive was simple, rhythmical enough and, probably, that served a definite purpose. Gradually the dancer, submitting to the rhythm, entered a certain mental condition. While dancing Skobar, having a rest from work and having fun on a festivity, a person, as a matter of fact, practised for a fist or stick fight. Ceremonial fights were also held to the accompaniment of music. The rules varied; for example, the fight lasted to the first blood or to the first fall. The accordion player (in the earlier times psaltery player) could stop the fight by stopping playing the tune. In this case, we can say that music had full power.

At the beginning of the 'affectation' the dancer shook his head or tousled his hair. These actions, certain exclamations (whooping) and stamping were considered as elements of the ancient folk magic. The person left his usual everyday space and entered another level of existence. Time flew differently, and sensory organs worked in a different way, and in general, the attitude to life or death was different. Therefore this awkward dance would actually serve rather as a cunning and effective preparation for fisticuffs. The relaxed body of a Skobar was ready to react not only to the actions of the rival, but even to a breeze whiff.

'Affectation' gradually passed into a ceremonial fight. This fight is a relic heritage of those times when men battled for a woman in a marriage fight. One of its names is Yar. On the other hand, the word 'Yar' meant vital force and its display in the Slavic languages. Considering themselves descendants of Dazhdbog - the god of Sun, or Yarila, they lived according to a solar calendar, and used vital energy in the struggle, in other words, the energy that was controlled by solar plexus.

Prepared for a serious fight by ceremonial 'affectation', in a critical situation a Skobar could join an internecine fight - to the complete annihilation of the opponent. A trained fighter could strike 5-6 blows a second. Such speed was defined by the principle of dance movements. To knock the opponent down, a Slav just needed to strike an indirect sliding blow. And it was better if it was 
delivered on a curved trajectory - the hand came back without a delay while another hand came nearer to the target. Such speed was important in the fight with several opponents, especially when in the encirclement (Retiunskikh \& Zaiashnikov 1991: 4-5; Gruntovskii 1998).

Traditions of the fisticuffs can be followed up to the second half of the 19th century. Their descriptions were published in 1878 in the magazine Pchela. So, for example, in Pskov, fights were held 'wall on wall - in an avalanche', some hundreds of people on each side. The fisticuffs was started by bullyboys due to some quarrel contrived in advance. Pushing each other, they started a formal fight from a tip-and-run attack.

"Hey, with a tip-and-run fight, from the front, from the sides, from heels to tops, I shall beat you up!" they shouted in thin voices, rolling up their sleeves and spitting on their fists. "Beat as you want, just don't touch the face, people say it is shameful!" (Krapivina 2000: 306-307).

Having started a tip-and-run fight to tease the senior fighters, kids used to be carried away by it and became so furious that they broke each other's noses, and their mothers would only sigh, watching the shreds of their red shirts fly up. But they did not stop the fighters as they were the 'leaders' to whom adult winners would buy new shirts. When they absolutely lost control, the 'real' fighters who were silent spectators of the attack to that moment, would take

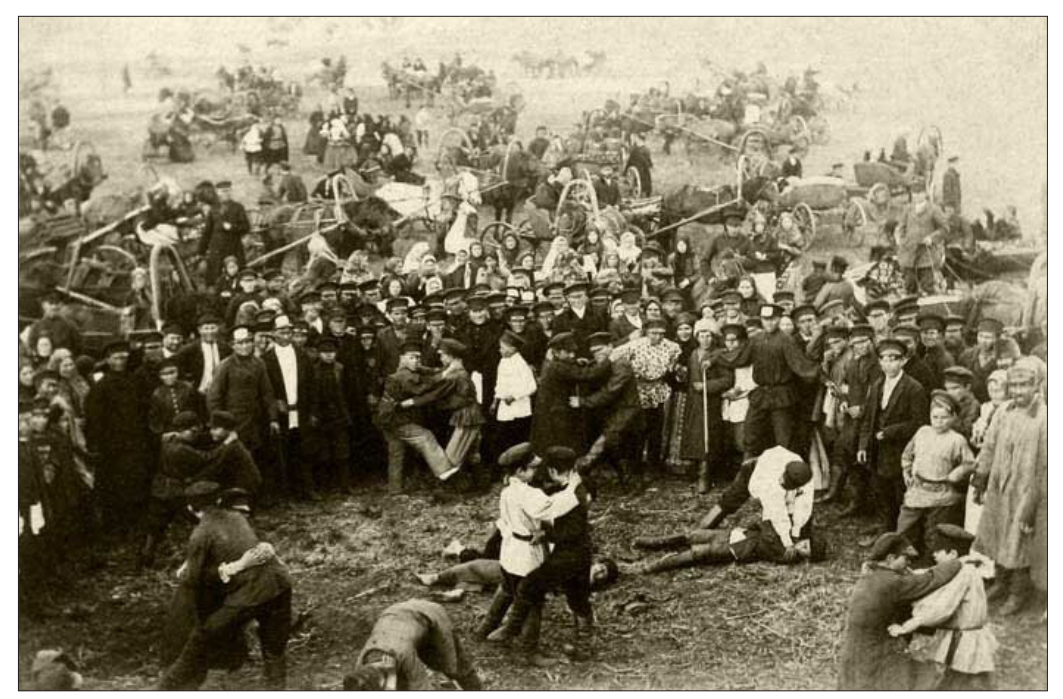

Figure 4. Fisticuffs. 1900. (http://fun247.ru/30.11.2012/vzglyad_v_istoriyu.html) 
them aside. After that the terrible 'valiant fun' began. There was always human blood, human bodies moaned and groaned under strong blows, and the crowd was delighted, both women and children's screams and men's curses were heard (ibid.).

Memories of the outstanding Pskov dwellers testify to the traditions of the fisticuffs. One of those sharing their memories was Yury Tynyanov (1894-1943), a Russian Soviet writer, playwright, literary critic, and the author of the novels Pushkin, Kukhlya, Vazir-Muhtara's Death, Second Lieutenant Kizhe, etc.

According to Yury Tynyanov, who entered Pskov Grammar School in 1904, in the first years of his studies fisticuffs was held between the city suburbs Zapskovie and Zavelichie that were at war with one another, and the pupils of the grammar school participated in them. Both sides beat the fighters for the coins clamped in the gloves (Tynyanov 2003: 112).

Other cities in the province were also famous for fisticuffs. In Velikiye Luki it was a usual youth entertainment at Christmastide and Shrovetide. Fisticuffs generally took place in a place named Butyrki where there was a district hospital later on. Now this place is known as a 'hospital town'. City dwellers set out on a fight against the peasants of Sergievskaya village, and even the officials took part in it. Sometimes fisticuffs ended very badly, some participants had battered faces, and others would even stay in bed. At the end of the 1860s, the police made every effort to stop such wild entertainment. Later on the youth occasionally showed their mighty force, under the influence of booze; at night they broke bridges and benches in parkways and streets, but they seldom showed their strength on people (Pul'kherov 1893: 78-79).

At the end of the 19th century fisticuffs was finally forbidden by the authorities. But physical strength was always respected in Russia, as well as a perfectly developed body. When a travelling circus came to the district cities, all the citizens went to watch its shows. Athletes broke horseshoes, juggled with twopood (33.6 kilograms) weights, knotted thick iron rods, lifted a wooden platform with ten spectators on their shoulders and wrestled with a bear. Many items in these 'shows' were invented by Estonian Georg Lurich, the world wrestling champion, who visited Velikiye Luki. It should be mentioned that his build was considered to be one of the best in Europe. It is known that the fighter posed for a well-known sculptor Rodin (Lopyrev 2003: 124).

Greco-Roman wrestling tournaments were extremely popular among the citizens of Pskov. Well-known foreign sportsmen were invited to take part in them. German Kentel, a world champion, visited Pskov on the eve of the First World War. During one of the fights he was defeated by an unknown smith of Pskov factory Metallist (Krasnopevtsev 1961; Krasnopevtsev 2002: 170-181). 
The first Russian boxers began as fisticuffers. Among them were Nur Alimov, Paul Nikiforov, etc. But it was not only representatives of wrestling and boxing that passed the remarkable school of fisticuffs. For example, the Starostin brothers well known in Russia (the founders of the sports society Spartak) spoke about this hobby with gratitude. Nikolay Starostin recollected:

Hand-to-hand fights ('wall on wall') were very popular in Moscow before the revolution... And group fights ('walls') had their own traditions. Some hundreds of people on each side took part in them. It could seem that it was a usual mass fight, a real slaughter. Actually it was a well-prepared show with its own stars and idols. As a rule, this kind of entertainment took place on Sundays and started usually at 10 a.m.

The spectators gathered on the coast of the Moskva River. Their number increased up to ten thousand by 3 or 4 p.m. 'Hand-to-hand' fights were held on ice ...

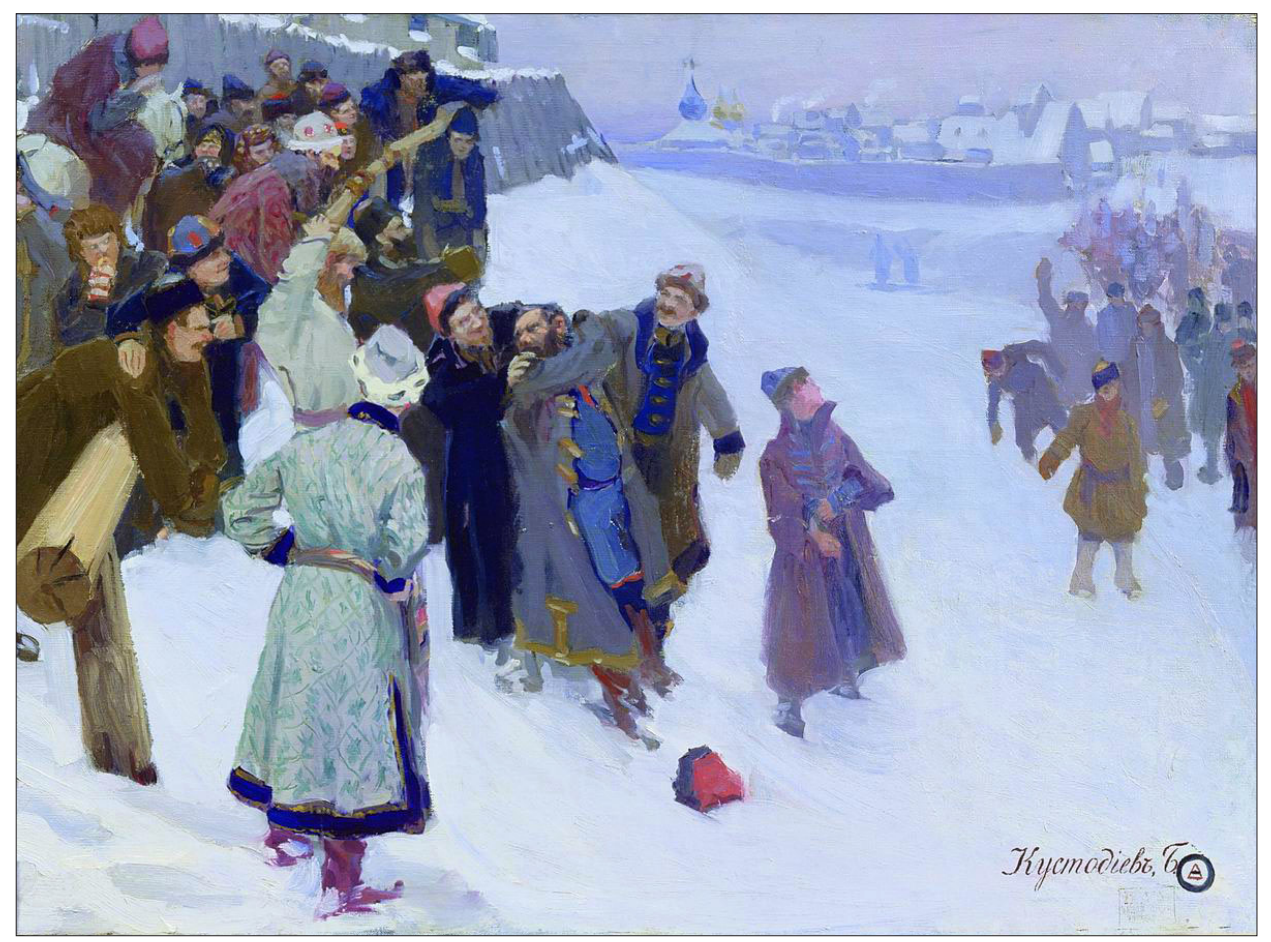

Figure 5. B. Kustodiev. Fisticuffs on the Moscow River. 1897. (http: / /5147690.ru/reproduktsiyakartiny-kulachnyi-boi-na-moskva-reke) 
The majority of us chose the opponent beforehand. As a rule, he was the same every time because we knew each other not the first year and tried, by the tradition of 'walls', to do so that opponents were approximately equal in strength ...

Certainly, our fight could not end in anything more dangerous than a bruise under an eye or a broken nose. Gloves on our hands softened blows, clothes and the lifted collars protected weak spots reliably. But we got badly tired. In order to rest, we sat down on ice and wiped sweat, sometimes mixed with blood ...

We were assured up to the end that we had won. On the opposite coast our opponents triumphed as well. This constituted a favourable emotional background of the notorious 'walls'. They did not produce enemies, did not sow civil strife, nor did they foster cruelty and revenge ...This way our characters were forged. In due course we began to take pride in participation in the 'walls'. Moreover, I am convinced that fair struggle and respect for the opponent, which became the idea of my existence in sports, originate in those 'hand-to-hand' fights on the Moskva River in 1916. (Goloshchapov 2007: 79-81)

The picture of national culture cannot be considered complete if the researcher has overlooked any of its components, and thus the logic of the studied ethnic culture has collapsed. Studying the local forms of national culture of the East Slavs is impossible without a reference to the traditions of hand-to-hand competitions.

The zone of the formation and evolution of the fisticuffs traditions by the East Slavs was the north-west of Russia, in particular the territory of modern Pskov area. Initially these lands were occupied by the East Slavic tribes of Novgorod and Krivichi, which allows us to see in the culture of fisticuffs a heritage of the ancient Slavic population of these territories.

So the fisticuffs traditions have a long history in the folk culture of Russia, extending from the Late Middle Ages until the beginning of the 20th century.

\section{REFERENCES}

Code of Laws 1832 = Polnoe sobranie zakonov Rossiiskoi imperii v 45 tomakh. [Code of Laws of the Russian Empire in 45 Volumes.] 1832. Sankt-Peterburg: Tipografiia Vtorogo otdeleniia Sobstvennoi Ego Imperatorskogo Velichestva kantseliarii.

Goloshchapov B. 2007. Istoriia fizicheskoi kul'tury i sporta. [History of Physical Education and Sport.] Moskva: Izdatel'skii tsentr Akademiia. 
Gorky 1949 = Gor'kii Maksim 1949. Zhizn' matveia Kozhemiakina. Sbranie sochinenii $v$ tridtsati tomakh. [Matvey Koshemyakin's Life. Collected Works in Thirty Volumes.] Moskva: Gosudarstvennoe izdatel'stvo khudozhestvennoi literatury.

Gruntovskii, A. 1998. Russkii kulachnyi boi: istoriia, etnografiia, tekhnika. [Russian Hand-to-Hand Fight: History, Ethnography, Technique.] Sankt-Peterburg: TOO Tekhnologiia avtomatizirovannykh system.

Krapivina, S. 2000. O pskovichakh (nechto v rode etnograficheskogo ocherka). [About Citizens of Pskov (some kind of ethnographic essay).] In: E. Ivanov (ed.) Sbornik dokumentov i materialov po istorii Pskovskogo kraia (IX-XX vv.). [Collected Documents and Materials on the History of Pskov Region (9th-20th cc.] Uchebnoe posobie. Pskov, pp. 304-315.

Krasnopevtsev, Valentin 1961. Poddubnyi v Pskove. [Poddubny in Pskov.] Molodoi Leninets (newspaper). Pskov, October 14.

Krasnopevtsev, Valentin 2002. Iz istorii pskovskogo sporta. [From the History of Sport in Pskov.] Pskov (journal), No. 17, pp. 170-181. http://pskgu.ru/projects/pgu/storage/ PSKOV/ps17/ps_17_22.pdf, last accessed on June 17, 2013.

Lermontov, Mikhail 1988. Pesnia pro tsaria Ivana Vasil'evicha, molodogo oprichnika $i$ udalogo kuptsa Kalashnikova. [The Song of Tsar Ivan Vassilevich, His Young Oprichnik, and the Stouthearted Merchant Kalashnikov.] Vol. 1. Moskva: Izdatel'stvo Pravda.

Lopyrev, Andrei 2003. U sporta muzhskoe litso. Velikolukskie byli. Istoriia kraia v dokumentakh i ocherkakh. [Sport Has a Masculine Face. Velikiye Luki Epics. History of the Region in Documents and Essays.] Pskov.

Pul'kherov, Aleksandr 1893. Obrazovanie i obrazovatel'nye sredstva v gorode Velikie Luki i ego uezde. Istoriko-statisticheskii ocherk. [Education and Means of Education in Velikiye Luki and its District. Historical-Statistical Essay.] Pskov: Tipografiia Pskovskogo gubernskogo statisticheskogo komiteta.

Retiunskikh, A. \& Zaiashnikov, S. 1991. Russkii stil' rukopashnogo boia (Stil' Kadochnikova). Metodicheskoe posobie dlia zanimaiushchikhsia russkim stilem rukopashnogo boia. [Russian Style of Hand-to-Hand Fight (Kadochnikov Style). Manual for Russian Hand-to-Hand Style Fighters.] Novosibirsk: Vest'.

Stolbov, V. \& Finogenova L. \& Mel'nikova, N. 2001. Istoriia fizicheskoi kul'tury i sporta. [History of Physical Education and Sport.] Moskva: FiS.

Tynyanov 2003 = Tynianov, Iurii 2003. Avtobiografiia. [Autobiography.] In: T. Veresova (ed.) Vnachale zhizni shkolu pomniu ia.... Lev Zil'ber, Veniamin Kaverin, Avgust Letavet, Nikolai Neigauz, Yury Tynyanov - o vremeni i o sebe. [I Remember School at the Beginning of My Life ...: Lev Zil'ber, Veniamin Kaverin, August Letavet, Nikolai Neigauz, Yury Tynyanov - About Times and About Myself.] Moskva: Moskovskaia Tipografiia. 